\title{
Büyükbaş Hayvan Atıkları ile Meyve Sebze Atıklarının Kompostlaştırılması Üzerine Nem İçeriğinin Etkisi
}

\author{
Yasemin BAYINDIR ${ }^{1}$, Nurdan Gamze TURAN ${ }^{2 *}$
}

\section{$\ddot{\mathbf{O z}}$}

Hayvan atıkları, birçok ürün için geleneksel bir besin kaynağıdır. Bununla birlikte, yüksek amonyak içeriği ve patojenler nedeniyle, doğrudan toprağa uygulandığında bitkiler açısından zararlı olabilmektedir. Kompostlaştırma, son yıllarda hayvan atıklarını yönetmek için yaygın olarak kullanılmaktadır. Kompostlanmış hayvan atıkları, ürüne ve toprağa birçok fayda sağlamaktadır. Saf hayvan atıkları, uygun şekilde kompostlaştırma için genellikle çok yüksek azot ve nem içeriğine sahiptir. Bu nedenle karbon/azot oranını ve nem içeriğini dengelemek için saman, odun kalıntısı veya yaprak gibi diğer organik maddelerle karıştırılabilmektedir. Bu çalışmada, büyükbaş hayvan atı̆̆ı ile meyve ve sebze atıklarının birlikte kompostlaştırılmasında nem içeriğinin etkisi araştırılmıştır. Kentsel katı atıklara \%10, \%25 ve \%40 oranlarında büyükbaş hayvan atığı ilave edilmiştir. 100 gün boyunca sıcaklık, pH ve nem içeriği parametreleri incelenmiştir. Elde edilen sonuçlar, büyükbaş hayvan atıklarının meyve sebze atıkları ile kompostlaştırıldığında nem içeriğinin dengelendiğini, kompostlaştırma için gerekli yüksek termofilik sıcaklık derecelerinin sağlandığını ve optimal pH aralığına ulaşıldığını göstermektedir.

Anahtar Kelimeler: Hayvan atıkları, Büyükbaş hayvan atığı, Kompostlaştırma, Birlikte kompostlaştırma, Meyve sebze atiklar1.

\section{Effect of Moisture Content on the Composting Process of Cattle Manure and Fresh Food Waste}

\begin{abstract}
Animal manure is a traditional source of nutrients for many crops. However, its high ammonia levels and pathogens can damage plants when the fresh manure is directly applied on soil. Composting has commonly used to manage animal manure in recent years. Composted animal manure can provide numerous benefits to the crop and soil. Pure manure is frequently too high in nitrogen and moisture content to be properly composted. Therefore, manure can be mixed with other organics such as straw, wood residue, or leaves to balance the carbon to nitrogen ratio and moisture content. In this study, the effect of moisture content on the co-composting of cattle manure and fresh food waste was investigated. Cattele manure was added to fresh food wastes at the rates of $10 \%, 25 \%$ and $40 \%$. The parameters of temperature, $\mathrm{pH}$ and moisture content were examined for 100 days. The results showed that when cattle manure are composted with fresh food wastes, the moisture content is balanced, the high thermophilic temperatures required for composting are provided and the optimal $\mathrm{pH}$ range is reached.
\end{abstract}

Keywords: Animal manure, Cattle manure, Composting, Co-composting, Fresh food wastes.

\footnotetext{
${ }^{1}$ Ondokuz Mayıs Üniversitesi, Mühendislik Fakültesi, Çevre Mühendisliği Bölümü, Samsun, Türkiye, gturan@omu.edu.tr

${ }^{2}$ Ondokuz Mayıs Üniversitesi, Mühendislik Fakültesi, Çevre Mühendisliği Bölümü, Samsun, Türkiye, yaseminbyndr94@gmail.com
} 


\section{Giriş}

Dünya nüfusunun hızla artması ve teknolojik alandaki gelişmeler sonucu katı atıklar gün geçtikçe artmakta ve insan ve çevre sağlığ1 üzerinde büyük bir risk oluşturmaktadır. Doğal kaynakların hızla tüketilmesinin önüne geçilmesi ve üretilen atıkların çevre ve insan sağlığı için bir tehdit olmaktan çıkarılarak ekonomi için bir girdiye dönüştürülmesini amaçlayan atık yönetim stratejileri, tüm dünyada giderek öncelikli bir politika hedefi olarak benimsenen "sürdürülebilir kalkınma" yaklaşımının temelini oluşturmaktadır.

Hayvancılık, gelişmişlik durumu ne olursa olsun tüm ülkeler için büyük önem arz etmektedir. Hayvancılık bir taraftan tarımsal işletmelere düzenli gelir sağlarken, diğer taraftan çeşitli sanayi kollarının hammadde ihtiyacını sağlayan önemli bir üretim dalıdır (DPT, 2001). Hayvancılık sektörü, büyükbaş hayvancılığı, küçükbaş hayvancılığı ve kanatlı hayvancılığı olarak gerçekleştirilmektedir. Bu kapsamda, süt ve kırmızı et ihtiyacının yaklaşık \%90'ının sağlandığı büyükbaş hayvan yetiştiriciliği büyük bir öneme sahiptir (KB, 2018). Türkiye'de büyükbaş hayvan sayısı 2020'de bir önceki yıla göre yüzde 1,6 artarak 18 milyon 158 bin olarak belirlenmiştir (TUIK, 2020). Bir büyükbaş hayvan yılda 11338-24490 kg (31-67 kg/gün) atık üretmektedir (Sims ve Maguire, 2005). Buna göre ülkemizde günde yaklaşık 563 bin ton ile bir milyon 217 bin ton arasında büyükbaş hayvan atığı oluşmaktadır.

Hayvancılık faaliyetlerinden kaynaklanan ve "İnsan Tüketimi Amacıyla Kullanılmayan Hayvansal Yan Ürünler Yönetmeliği”" kapsamında değerlendirilemeyen hayvan dışkılarının atık olarak yönetilmesi gerekmektedir. 02.04.2015 tarihli ve 29314 sayılı Resmî Gazetede yayımlanan Atık Yönetimi Yönetmeliği EK-4 atık listesinde; hayvan dışkıları, 020106 atık kodu ile verilmekte ve ayrı toplanmış ve saha dişında işlem görecek hayvan pislikleri, idrar ve tezek (pisletilmiş saman dahil), akan sıvılar olarak tanımlanmaktadır. Bu tür atıkların, çevre mevzuatı çerçevesinde "Kompost Tebliğì", "Mekanik Ayırma, Biyokurutma, Biyometanizasyon ile Fermente Ürün Yönetimi Tebliği”" veya "Atıkların Yakılmasına İlişkin Yönetmelik” çerçevesinde bertarafının sağlanması gerekmektedir. Hayvan dışkılarının “Atıkların Yakılmasına İlişkin Yönetmelik” te tanımlanan yakma tesisleri haricindeki yakma kazanlarında veya yakma firınlarında yakılması veya "Atıkların Düzenli Depolanmasına Dair Yönetmelik" te tanımlanan düzenli depolama tesislerinde bertaraf edilmesi uygun bulunmamaktadır (ÇSB, 2020).

Hayvan atıklarının yönetiminde kompostlaştırma en etkin yöntemlerden birisidir. Kompostlaştırma, organik atıkların aerobik koşullar altında kompost adı verilen humusa benzer bir ürün haline dönüştürüldüğü biyokimyasal bir süreçtir. Hayvan atıklarının kompostlaştırılması düşük üretim maliyeti, toprak yapısını düzenleme ve ürün verimini artırma gibi avantajlara sahiptir (Nyamangara ve ark., 2001; Materecheraand ve Salagae, 2002). Diğer yandan, saf hayvan atıkları ve 
sentetik gübrelere kıyasla, yeraltı ve yüzey sularına nütrient kayıplarını azaltmakta ve toprağın azot seviyesini dengelemektedir (Hepperly ve ark., 2009).

Hayvan atıkları ve kentsel katı atıklar kompostlaştırma için uygun atıklar olmasına rağmen, yüksek azot ve nem içeriği nedeniyle katkısız kompostlaştırılmasında sorunlar yaşanmaktadır. Bu nedenle saman, odun kalıntısı veya yaprak gibi diğer organik maddelerle karıştırılabilmektedir. Kullanılan katkı maddeleri ortamın karbon/azot oranını ve nem içeriğini dengelemektedir (Haug, 1993).

$\mathrm{Bu}$ çalışmada, büyükbaş hayvan atıkları ile kentsel katı atıkların birlikte kompostlaştırılabilirliğinde nem içeriğinin etkisi incelenmiştir. Farklı oranlarda karışımlar oluşturulmuş ve kapalı sistemde kompostlaştırma uygulanmıştır. Proses süresince nem içeriğgi, sıcaklık ve pH incelenmiş ve 05.03.2015 tarih ve 29286 sayılı Resmi Gazete'de yayımlanan “Kompost Kalite Tebliği” ne göre değerlendirilmiştir. Sonuçlar sadece hayvan atıkları ve sadece kentsel katı atıkların kompostlaştırıldığı sistemlerle karşılaştırılmıştır.

\section{Materyal ve Metot}

Bu çalışmada, büyükbaş hayvan atıkları Ondokuz Mayıs Üniversitesi Ziraat Fakültesi hayvan çiftliğinden, meyve sebze atıkları da Samsun ilinde meyve ve sebze halinden temin edilmiştir. Atık örnekleri 10 L'lik plastik kaplarla alınmış ve 4 saati aşmayan sürede sistemlere yerleştirilmiştir. Çalışma, Mayıs-Ağustos 2019 tarihleri arasında laboratuar ortamında gerçekleştirilmiştir.

Pilot kompostlaştırma sistemleri kapalı reaktör tarzında tasarlanmıştır. Pilot reaktör, kompost oluşumunun devamlı izlenmesi için şeffaf plastikten imal edilmiştir. Reaktörün hacmi $30 \mathrm{~L}$ olup ölçüleri $40 \mathrm{~cm}$ x $30 \mathrm{~cm}$ x $25 \mathrm{~cm}$ (en x boy x yükseklik) şeklindedir. Tabandan $5 \mathrm{~cm}$ yükseklikte, $2 \mathrm{~cm}$ çaplı PVC borudan yatayda ve düşeyde tarak şeklinde havalandırma teçhizatı döşenmiştir. Akvaryum pompasına bağlantısı olan ana boru dışındaki tüm borularda $3 \mathrm{~mm}$ çapında çaprazlama delikler açılmıştır. Akvaryum pompasının kapasitesi tüm sistemlerde aynı olup, kompostlaştırma prosesi süresince $10 \mathrm{~L} /$ dak. olarak çalıştırılmıştır. Gaz çıkış1 ve sıcaklık ölçümü için kapak kısmında birer baca oluşturulmuştur. Deneylerde kullanılan kompostlaştırma sisteminin şematik görünümü Şekil 1'de verilmiştir. 


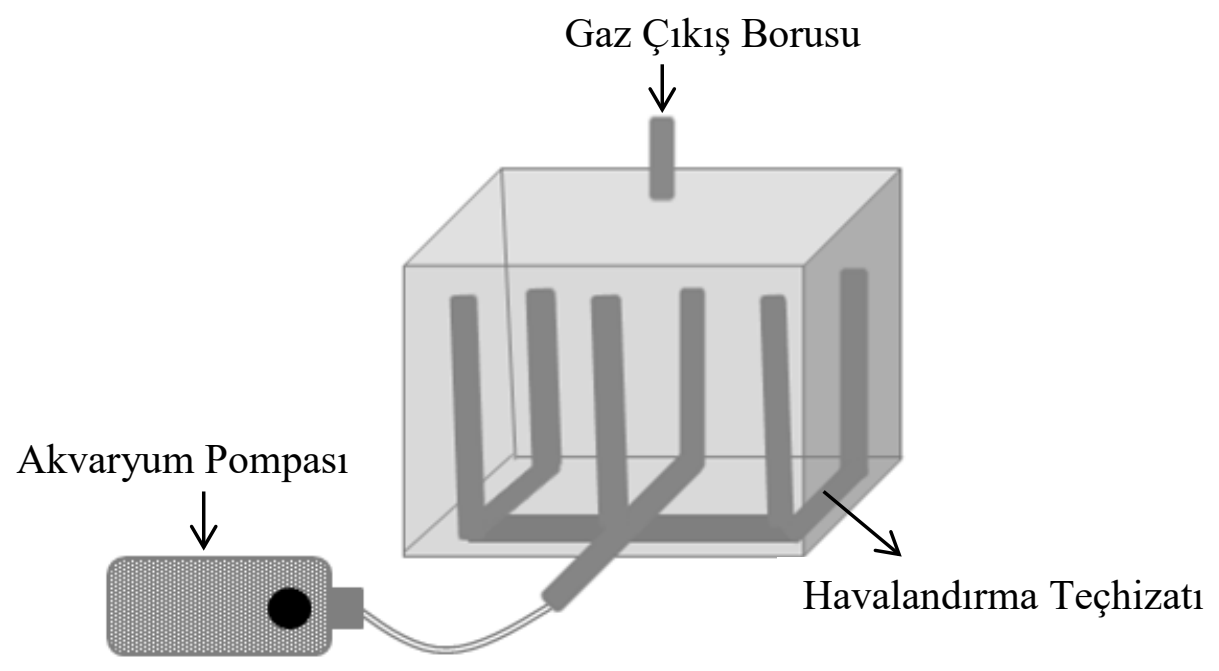

Şekil 1. Pilot kompostlaştırma reaktörünün şematik görünümü

Numune alma periyodu, haftada bir kez olarak gerçekleştirilmiş ve 100 gün (15 hafta) boyunca devam etmiştir. Çalışmada 5 farklı materyal oranı ile kompostlaştırma denemesi gerçekleştirilmiştir. Materyal oranları Tablo 1'de verilmektedir.

Tablo 1. Kompost denemelerinde kullanılan materyal oranları

\begin{tabular}{lc}
\hline Set No & Karışım Oranı \\
\hline Set 1 & $\% 10$ Büyükbaş Hayvan Atı̆̆ $1+\% 90$ Kentsel Katı Atık \\
Set 2 & $\% 25$ Büyükbaş Hayvan Atı̆̆ $1+\% 75$ Kentsel Katı Atık \\
Set 3 & $\% 40$ Büyükbaş Hayvan Atığ $1+\% 60$ Kentsel Katı Atık \\
Set 4 & $\% 100$ Büyükbaş Hayvan Atığ 1 \\
Set 5 & $\% 100$ Kentsel Katı Atık \\
\hline
\end{tabular}

Alınan kompost numunelerinde, sıcaklık, pH ve nem içeriği ölçümleri yapılmıştır. pH ve nem içeriği analizleri, orijinal atık numunesi ile gerçekleştirilmiştir. Analizlerde kompost için standart yöntemler kullanılmıştır (FCQAO, 1994). pH analizi için, 1:10 (w:v) oranında kompost ve saf su karışımı hazırlanarak mekanik çalkalayıcıda $180 \mathrm{dev} / \mathrm{dk}$ ile 1 saat çalkalanmıştır. Çalkalama sonunda pH ölçümü, Mettler Toledo-MP220 marka pH metre ile yapılmıştır. Nem içeriği, numunelerin etüvde $105{ }^{\circ} \mathrm{C}^{\prime} \mathrm{de} 24$ saat bekletildikten sonra meydana gelen ağırlık kaybından aşağıdaki şekilde hesaplanmıştır:

Nem İçeriği $(\%)=(A-B) / A x 100$

Burada;
A: Numunenin kurutulmadan önceki ağırlığ1
B: Numunenin kurutulduktan sonraki ağırlığı 
Deneyde, nem içeriğinin tayininde kullanılan etüv Nüve-FN400 markadır. Sıcaklık ölçümü için ise Loyka-9263 digital çubuk termometre kullanılmıştır.

\section{Bulgular ve Tartışma}

Kompostlaştırma prosesinde nem içeriği mikroorganizmaların metabolik faaliyetlerinde ihtiyaç duydukları çözünmüş besinlerin taşınması için ortam oluşturduğundan önemli bir parametredir. Nem içeriği mikrobiyolojik faaliyetleri, sıcaklığı ve ayrışma hızını etkilemektedir (Bernal ve ark., 2009). Kompostlaştırma prosesinin etkin bir şekilde devam ettirilmesi için nem içeriğinin \%50-60 arasında olması gerekmektedir (Epstein, 2011). Düşük nem içeriği değerleri, mikrobiyolojik etkinliği büyük miktarda düşürür. Diğer taraftan nem içeriğinin fazla olması komposttaki hava boşluklarının su ile dolarak ortamın anaerobik duruma gelmesine ve besin kayıplarına sebep olur. Kompostlaştırma prosesi süresince nem içeriğinin değişimi Şekil 2'de verilmiştir. Kompostlaştırma prosesi başlangıcında, \%100 büyükbaş hayvan atığı içeren Set 4'te ve büyükbaş hayvan atığı ile kentsel katı atık karışımlarından oluşan Set 1, Set 2 ve Set 3 'te proses başlangıcında nem içeriği değerleri optimum aralığın üzerinde yer almıştır. Nem içeriği değeri \%100 meyve ve sebze atıklarını içeren kentsel katı atıkların yer aldığı Set 5'te ise yaklaşık \%70 olarak belirlenmiştir. Nem içeriği değerleri, organik maddenin parçalanması ve oluşan ısı sonucu buharlaşma ile proses süresince azalma göstermiştir. Proses sonunda nem içeriği değerleri, \%10 büyükbaş hayvan atığı ve \%90 kentsel katı atık içeren Set 1'de, \%25 büyükbaş hayvan atığ1 ve \%75 kentsel katı atık içeren Set 2'de, \%40 büyükbaş hayvan atığ1 ve \%60 kentsel katı atık içeren Set 3'te ve \%100 büyükbaş hayvan atığı içeren Set 4'te \%20-30 arasında bulunmuştur. \%100 kentsel katı atık içeren Set 5'te ise \%50 olarak ölçülmüştür. Kompost Tebliği’nin Ek-2 “Kompost Kalite Parametreleri” bölümünde kaliteli bir kompost üretimini sağlamak için kompostun nem içeriği değerinin \%30'dan küçük olması gerektiği belirtilmektedir. Buna göre, \%10 büyükbaş hayvan atığ1 ve \%90 kentsel katı atık içeren Set 1'de, \%25 büyükbaş hayvan atığ ve $\% 75$ kentsel katı atık içeren Set 2'de; \%40 büyükbaş hayvan atığı ve \%60 kentsel katı atık içeren Set 3 'te ve \%100 büyükbaş hayvan atığ içeren Set 4'te üretilen kompostların nem içeriği değerleri kompost kalite kriterleri açısından uygunken; \%100 kentsel katı atık içeren Set 5'te üretilen kompostların nem içeriği değerleri kompost kalite kriterleri açısından uygun değildir.

Kentsel katı atıkların yüksek nem içeriği, kompostlaştırma prosesi süresince sıcaklık değişimini de önemli ölçüde etkilemiştir. Tüm sistemlerde sıcaklık değerleri ilk 3 hafta boyunca artış göstermiş, sonrasında ise azalan bir eğri sergilemiştir. 7. haftadan sonra sıcaklık değerlerinde önemli değişim gözlenmemiştir. Kompost Tebliğii'nin 11. maddesi 5. bendinde 
hayvansal atık kullanılması durumunda, kompostlaştırma ünitesinde $70{ }^{\circ} \mathrm{C}$ sıcaklı̆̆ın en az 1 saat boyunca kesintisiz olarak sağlanması gerektiği belirtilmektedir. Maksimum sıcaklık değerleri, \%10 büyükbaş hayvan atığ1 ve \%90 kentsel katı atık içeren Set 1'de; \%25 büyükbaş hayvan atığ1 ve $\% 75$ kentsel katı atık içeren Set 2'de ve \%40 büyükbaş hayvan atığı ve \%60 kentsel katı atık içeren Set 3 'te $60-70{ }^{\circ} \mathrm{C}$ olarak ölçülmüştür. Büyükbaş hayvan atığı ve kentsel katı atık karışımı ile gerçekleştirilen her üç sette de Kompost Tebliği'nde öngörülen sıcaklık derecelerine tam olarak ulaşılamamıştır. \%100 büyükbaş hayvan atığı içeren Set 4'te ve \%100 kentsel katı atık içeren Set 5'te ise maksimum sıcaklık değerleri $50{ }^{\circ} \mathrm{C}$ 'nin altında gözlenmiştir. Gerek sadece kentsel katı atıkların, gerekse sadece büyükbaş hayvan atıklarının kompostlaştırıldığı setlerde mikrobiyal aktivite ile organik maddelerin parçalanması sonucu beklenen 1sı artışının, istenilen oran ve sürede gerçekleşmemiş olduğu görülmüştür. Bunun nedeninin, \%100 büyükbaş hayvan atığı içeren setteki porozitenin daha düşük olmasından ve \%100 kentsel katı atık içeren setteki yüksek nem içeriğinden kaynaklandığı düşünülmektedir. Bu setlerde, partiküller arası boşluklar su ile dolarak 1sınmayı engellemiştir.

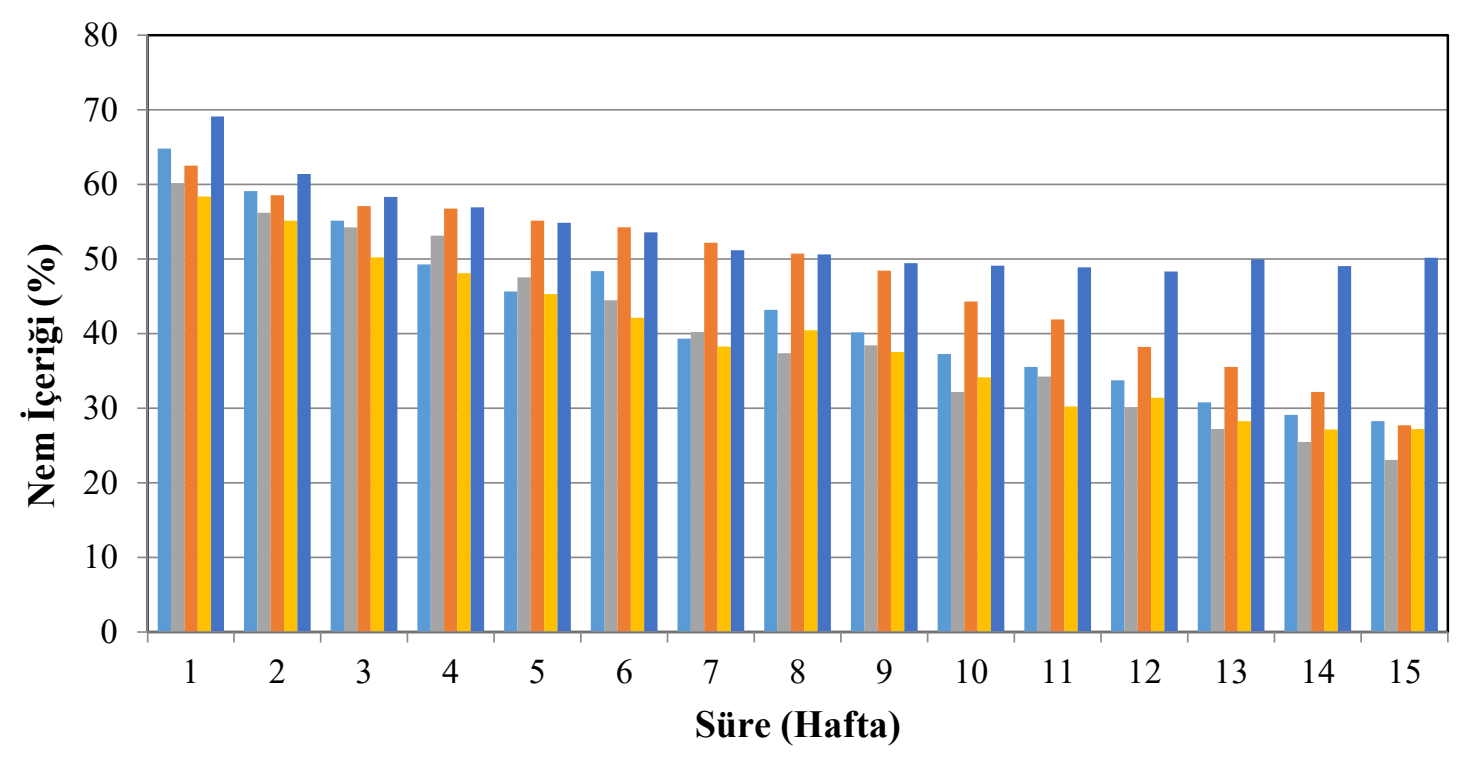

$\square$ Set $1 \square$ Set $3 \square$ Set $2 \square$ Set $4 \square$ Set 5

Şekil 2. Kompostlaştırma prosesi süresince nem içeriğinin değişimi

Kompostlaştırma prosesinde $\mathrm{pH}$ önemli bir parametredir. Yüksek pH değerleri ortamdan azot kaybına ve koku problemine neden olmaktadır. Tüm sistemlerde pH değerleri sıcaklığın pik yaptığı 3. haftaya kadar hızlı bir azalma göstermiştir. Bu azalmaların, organik maddenin ilk haftalarda hızla parçalanarak $\mathrm{CO}_{2}$ ve organik asit oluşturmasından dolayı meydana geldiği belirtilmektedir. pH değeri, 3. haftadan sonra tüm sistemlerde artış göstermiştir. 9. haftadan sonraki pH değişimleri ise önemli salınımlar göstermemiştir. Kompostlaştırma proseslerinde, $\mathrm{pH}$ 
8,5'dan büyük olduğunda azot bileşikleri amonyağa dönüşmektedir. pH'nın 8'den küçük olmasının amonyak oluşumunu azalttığı belirtilmektedir (Öztürk, 2017). Kompostlaştırma prosesi sonunda \%100 büyükbaş hayvan atığı içeren Set 4'te ve \%100 kentsel katı atık içeren Set 5'te pH değerleri 8'in üzerinde bulunmuştur. pH değerleri, \%10 büyükbaş hayvan atığ1 ve \%90 kentsel katı atık içeren Set 1'de, $\% 25$ büyükbaş hayvan ve \%75 kentsel katı atık içeren Set 2'de ve \%40 büyükbaş hayvan atığ ve \%60 kentsel katı atık içeren Set 3'te 6-7 arasında belirlenmiştir. Atıkların yüksek nem içeriğinin pH değişimi üzerine de etkili olduğu görülmektedir. Kompost Tebliği'nin Ek-2 "Kompost Kalite Parametreleri” bölümünde kaliteli bir kompost üretimini sağlamak için pH değerinin 5.5-8.5 arasında olması gerektiği belirtilmektedir. Buna göre, \%100 büyükbaş hayvan atığ1 içeren Set 4'te ve \%100 kentsel katı atık içeren Set 5'te pH değeri oldukça yüksek bulunmuştır. \%10 büyükbaş hayvan atığ ve \%90 kentsel katı atık içeren Set 1'de; \%25 büyükbaş hayvan atığ 1 ve \%75 kentsel katı atık içeren Set 2'de ve \%40 büyükbaş hayvan atığı ve \%60 kentsel katı atık içeren Set 3'te proses sonunda üretilen kompost pH değerleri kompost kalite kriterleri açısından uygundur.

\section{Sonuçlar ve Öneriler}

$\mathrm{Bu}$ çalışmada, büyükbaş hayvan atıklarının meyve ve sebze atıkları ile kompostlaştırılaması üzerine nem içeriğinin etkisi incelenmiştir. Kentsel katı atıklara \%10, \%25 ve $\% 40$ oranlarında büyükbaş hayvan atığı ilave edilmiştir. Kompostlaştırma prosesi süresince sıcaklık, pH ve nem içeriği parametreleri incelenmiştir. Aynı koşullarda sadece kentsel katı atık ve sadece büyükbaş hayvan atığı da kompostlaştırmaya tabi tutulmuş ve veriler karşılaştırılmıştır. Elde edilen sonuçlar, gerek \%100 oranında kentsel katı atıkların, gerekse \%100 oranında büyükbaş hayvan atıklarının kompostlaştırılması ile elde edilen kompostların 05.03.2015 tarih ve 29286 sayılı Resmi Gazete'de yayımlanan Kompost Tebliği'nde verilen kalite kriterlerini karşılamadığı görülmüştür. Kentsel katı atıklarla büyükbaş hayvan atıklarının birlikte kompostlaştırılması ile elde edilen kompostun özelliklerine bakıldığında, sıcaklık dışındaki tüm kalite kriterlerinin sağlandığı belirlenmiştir. S1caklık değerleri, tebliğde öngörülen sıcaklık derecelerine ulaşmamakla birlikte, oldukça yakındır. Sonuç olarak, büyükbaş hayvan atıkları ile kentsel katı atıkların birlikte kompostlaştırılabileceği ve birlikte kompostlaştırmanın kompost kalitesini arttırdığı gözlenmiştir. Kompostlaştırma bu tür atıkların bertarafında çevresel ve ekonomik kazançlar sağlanmasına yardımcı olacaktır. 


\section{Yazarların Katkısı}

Makale, Yasemin Bayındır'ın Yüksek Lisans tez çalışmasından üretilmiştir. Prof. Dr. Nurdan Gamze Turan ise tez danışmanı olup, tez çalışmasını yönetmiştir.

\section{Çıkar Çatışması Beyanı}

Yazarlar arasında herhangi bir çıkar çatışması bulunmamaktadır.

\section{Araştırma ve Yayın Etiği Beyanı}

Yapılan çalışmada araştırma ve yayın etiğine uyulmuştur.

\section{Kaynaklar}

Bernal, M.P., Alburquerque, J.A., Moral, R., 2009. Composting of animal manures and chemical criteria for compost maturity assessment. Rev. Bioresour. Technol. 100 (22), 5444-5453.

ÇSB, 2020. Hayvansal Atık Yönetimi. Retrieved from https://bartin.csb.gov.tr/hayvansal-atik-yonetimi-haber64223

DPT, 2001. Hayvancılık Özel İhtisas Komisyonu Raporu, Sekizinci Beş Yıllık Kalkınma Planı, 2001.

Epstein, E., 2011. Industrial Composting: Environmental Engineering and Facilities Management, CRC Tailor \& Francis Group Press, Boca Raton.

FCQAO, 1994. Methods Book for Analysis of Compost, Federal Compost Quality Assurance Organisation, Stuttgart, Germany.

Haug, R.T., 1993. The Practical Handbook of Compost Engineering, Lewis Publishers, Boca Raton.

Hepperly, P., Lotter, D., Ulsh, C.Z., Reider, C., 2009. Compost, manure and syntheticfertilizer influences crop yields, soil properties, nitrate leaching and crop nutri-ent content. Compost Science \& Utilization, 17, 117-126.

KB, 2018. Tarım ve Gıdada Rekabetçi Üretim, Özel İhtisas Komisyonu Raporu, Kalkınma Bakanlığı, Ankara.

Materechera, S.A., Salagae, A.M., 2002. Use of partial decomposed cattle and chickenamended with woodash in two South African arable soils with contrasting tex-ture: effect on nutrient uptake, early growth and dry matter yield of maize. Communications Soil Science and Plant Analysis, 33, 179-201.

Nyamangara, J., Gotosa, J., Mpofu, S.E., 2001. Cattle manure effect on structural sta-bility and water relation capacity of granitic soil in Zimbabwe. Soil Tillage Research, 62,157-162.

Öztürk, M. Hayvan Gübresinden Ve Atıklardan Kompost Üretimi

Öztürk, M., 2017. Hayvan Gübresinden ve Atıklardan Kompost Üretimi, Çevre ve Şehircilik Bakanlığı, Ankara.

Sims, J.T., Maguire, R.O., 2005. Manure Management, Encyclopedia of Soils in the Environment, Ed. D. Hillel, Elsevier Ltd, 402-410.

TUIK, $2020 . \quad$ Hayvansal Üretim İstatistikleri, Retrieved from https://data.tuik.gov.tr/Bulten/Index?p=Hayvansal-Uretim-Istatistikleri-Aralik-2020-37207, 